\title{
Problemy oświatowe w dziewiętnastowiecznych austriackich szematyzmach wojskowych
}

\section{Wstęp}

Zgodnie z krążącą przed I wojną światową (i nie tylko) anegdotą, o audiencję ${ }^{1}$ do cesarza Franciszka Józefa I poprosił pewien starosta, którego syn, oficer kawalerii, przegrał w karty poważną sumę 30 tys. koron. Zaciągnął dług honorowy, którego niespłacenie w terminie skutkowałoby koniecznością samobójstwa. Zdesperowany ojciec przybył przed oblicze cesarza i przedstawił mu prośbę o pomoc. Monarcha wysłuchał jej i miał powiedzieć:

- A ja ojca pańskiego znałem; był także starostą, tylko w Grazu. Ależ panie, ja dziadka pańskiego znałem, był sekretarzem sądu najwyższego już wtedy, kiedy wstąpiłem na tron... Trzydzieści tysięcy koron. Jakaż to ogromna kwota... Ale to już czwarte pokolenie, które mnie służy. Zobaczę, co się da zrobić.

Następnego dnia starosta otrzymał wiadomość od syna, że cesarz zapłacił dług z własnej szkatuły ${ }^{2}$.

Skąd cesarz znał takie szczegóły? Czy miał tak dobrą pamięć? Owszem, to jedno. $Z$ drugiej strony, ponoć jedyne książki, jakie czytał, to tzw. schematyzmy (szematyzmy ${ }^{3}$ ), czyli wychodzące rok po roku spisy wszystkich urzędników i wojskowych w państwie austriackim. Właśnie na analizie jednej serii tych wydawnictw - na tzw. szematyzmach wojskowych - chciałbym oprzeć moje opracowanie.

* Mgr, doktorant, Zakład Historii Polski Nowoczesnej, Instytut Historii, Wydział Historyczny, Uniwersytet Jagielloński, ul. Gołębia 13, 31-007 Kraków.

1 Na których podczas swego panowania przyjął ponad 100 tys. swoich poddanych. Por. S. G r o d z i c k i, Franciszek Józef I, Wrocław 1983, s. 113.

2 Tamże, s. 152-153.

3 Forma „szematyzm” przyjęła się w środowisku galicyjskim i dlatego w treści niniejszego artykułu sukcesywnie będę używał właśnie tej spolszczonej wersji. 
Wychodzące od 1790 r. Militär-Schematismus des österreiechischen Kaiserthumes liczyły od dwustu pięćdziesięciu do prawie dwóch tysięcy stron zapełnionych nazwiskami oraz przydziałami oficerów, kandydatów oficerskich oraz urzędników wojskowych.

Wydaje się, że w tego typu źródłach nie można znaleźć informacji przydatnych w badaniach historii oświaty. Nic bardziej błędnego. Owszem, dane w nich zamieszczone są bardzo specyficzne, lecz mimo to przydatne przynajmniej dla badacza dwóch zagadnień. Po pierwsze, dzięki szematyzmom wojskowym można w dokładny sposób zająć się strukturą organizacyjną szkolnictwa wojskowego, funkcjonującego w monarchii austriackiej - zmianami tej organizacji oraz częściowo zmianami programów szkolnych tam obowiązującymi. Po drugie, dzięki analizie szematyzmów można znaleźć informacje na temat wspierania budowy systemu oświaty (zwłaszcza wojskowej) przez darczyńców państwowych i prywatnych poprzez tworzenie systemu fundacji oświatowych.

W moim artykule przedstawię pokrótce zawartość „oświatową” poszczególnych, wybranych roczników.

\section{Opis źródła}

Szematyzmy wojskowe są przykładem periodyku sprawozdawczego, charakterystycznego dla monarchii austriackiej w XIX i na początku XX w. Katalogi austriackiej Biblioteki Narodowej (Österreichische Nationalbibliothek) wykazują ponad pół tysiąca rekordów spełniających zapytanie "Schematismus”, z czego zdecydowana większość dotyczy monarchii austriackiej.

Szematyzmy austriackie wiązały się z różnymi dziedzinami życia w monarchii, można je jednak podzielić na kilka grup. Przede wszystkim kryterium podziału może stanowić zasięg terytorialny wydawnictwa oraz jego „urzędowość” na poziomie instytucji centralnych. Takie kryteria spełniały dwa wydawnictwa - szematyzm wojskowy (pod różnymi tytułami monarchii opisanymi poniżej) oraz Hof-und Staats-Schematismus des oesterreichischen Kaiserthumes, będący cywilnym odpowiednikiem rocznika wojskowego. Druga grupa wydawnictw tego typu to periodyki dotyczące poszczególnych krajów koronnych, czyli de facto skrócone wersje wydawnictw wymienionych w poprzednim punkcie ${ }^{4}$. Kolejny typ roczników personalnych to wydawnictwa poświęcone poszczególnym instytucjom, urzę-

${ }^{4}$ Szematyzmy krajowe to np.: Schematismus des Erzherzogthums Oesterreich ob der Enns Oberösterreich, Salzburg-Linz 1788-1843; Schematismus von Tirol und Vorarlberg, Innsbruck 1836-; Titularkalender (Titularcalender) oder Schematismus für Mähren und Schlesien, Brünn 1799-1807; Szematyzm Królestwa Galicji i Lodomerii wraz z Wielkim Księstwem Krakowskim na rok..., Lwów; Handbuch der Behörden in Tirol und Vorarlberg, Innsbruck 1858-; Schematismus für das Kronland Mähren, Brünn 1855; Schematismus der autonomen Landes-, Bezirks- und Gemeinde-Organe im Kronlande Steiermark, Graz 1869. 
dom oraz grupom zawodowym, np. urzędnikom skarbowym ${ }^{5}$, pracownikom kolei żelaznych ${ }^{6}$, nauczycielom ${ }^{7}$, służbie zdrowia $^{8}$, a także niektórym towarzystwom zawodowym ${ }^{9}$. Dodatkowo istniały szematyzmy duchowieństwa poszczególnych diecezji1 ${ }^{10}$, zgromadzeń zakonnych ${ }^{11}$ lub wyznań zreformowanych ${ }^{12}$. Pojawiały się

${ }^{5}$ Na przykład Szematyzm galicyjskich władz, nadzorów, oddziałów i członków c.k. Straży Skarbu ułożył i wydał Alojzy Bizub, Lwów 1880; Shematismus der mährischen Finanz-Verwaltung, Brünn 1909-; Schematismus der k.k. Finanzbeamten des österr. Kaiserstaates. Manual nomenclativo degli impiegati di finanza della monarchia austriaca, Graz 1858.

6 Szematyzm c.k. uprzywilejowanej kolei galicyjskiej Karola Ludwika zestawił $i$ wydał w miesiącu lutym 1890 Feliks Robert Hahn sekretarz Dyrekcjyi ruchu c.k. uprzyj. kolei galicyjsk. Karola Ludwika, Lwów 1890; Eisenbahn- Schematismus für Oesterreich-Ungarn, Wien 1888-; Schematismus der k.k. a. p. Kaiser Ferdinands-Nordbahn, Wien 1860.

7 Szematyzm obejmujący wszystkich nauczycieli przy szkołach narodowych w Tarnowskiej dyecezyi biskupiej obrządku łacińskiego znajdujących się na rok 1854, Tarnów 1854; Schematismus sämmtlicher Volks-Schulen und Volksschul-Lehrer in der Markgrafschaft Mähren, Olmütz (Ołomuniec) 1862; Schematismus der Bukowiner Volksschulen und Lehrer. (Zsgst. auf Grundlage amtlicher Daten.), Czernowitz (Czerniowce) 1894; Sematizm narodnych skol i ucitelej v archieparchii L'Vovskoj gr.-katol. mitropolital'noj konsistorii. (Schematismus der Volksschulen und Lehrer der Lemberger Metropolie des griechischen Ritus), Lwów 1866-; Szematyzm nauczycieli i nauczycielek szkół wydziałowych i pospolitych miejskich w Krakowie w roku 1903, Kraków 1903; Szematyzm szkół ludowych, zostających pod nadzorem Iwowskiego Konsystorza metropolitalnego obrządku łacińskiego, Lwów 1865-; Szematyzm szkół ludowych i nauczycieli w obrębie krakowskiego Okręgu szkolnego zamiejskiego i miejskiego, tudzież Seminaryów nauczycielskich w Krakowie, Kraków 1872-.

${ }_{8}$ Medicinal- Schematismus der graduirten und diplomirten Aerztej Thierärzte, Apotheker (etc.) Oesterreich-Ungarns, Wien 1893-.

9 Chemiker-Schematismus. Hrsg. vom Verein oesterreichischer Chemiker, Wien 1911-; Schematismus des Vereins zur Beförderung und Unterstützung der Industrie und der Gewerbe in Innerösterreich, Grätz 1839; Az erdelyi gardasagi egylet Nevkönyve. (Schematismus des siebenbürglschen landwirthschaftlichen Verein), Kolozsvar 1860-; Szent-Istvan tarsulat Nevkönyve. (Schematismus des St. Stephans- Vereins), Pest 1858-;

10 Zarówno dla kleru greko- jak i rzymskokatolickiego np. Universalis schematismus ecclesiasticus venerabilis cleri romano-et graeco-catholici saecularis et regularis regni Hungariae partiumque eidem adnexarum, necnon magni principatus Transilvaniae ... pro anno 1842/3 Reesch de Lewald, Aloysius, Budae 1842; Schematismus venerabilis cleri archidioecesis Strigoniensis, Tyrnaviae (Tyrnawa) 1821-1940; Sematizm vsego klira greko-katoliceskogo Eparchii sojedinenych Peremyskom, Samborskom i Sjanockom, Przemyśl 1868; Schematismus der Geistlichkeit der Diözese Linz in Oberösterreich, Linz 1866-.

11 Schematismus patrum, fratrum et monialium ordinis Eremitarum S.P Augustini in magno ducatu Cracoviensi, Cracoviae 1889- ; Schematismus Ordinis Minorum S.P. Francisci Conventualium almae provinciae Austriaco-Styriacae provinciae Austriaco-Styriacae, Viennae (Wiedeń) 1905-; Schematismus ordinis servorum B.M.V. almae provinciae Austriac- Hungaricae, Vindobonae (Wiedeń) 1894-; Schematismus patrum ac fratrum ordinis Minorum S. Francisci regularis observantiae vulgo Bernardinorum provinciae Galicianae, Leopoli (Lwów) 1839-; Schematismus provinciae S. Hyacinth ordinis Praedicatorum in regnis Galiciae et Lodomeriae existentium, Leopoli (Lwów) 1840-; Schematismus patrum ac fratrum recollectorum provinciae b. virg. Mari dolorosae per Galiciam, Ressovia (Rzeszów) 1847.

${ }^{12}$ A dunamelleki helvet hitvallasu egyhazkerület Nevtara. (Schematismus des Donau-Kirchendistricts helvet. Confession.), Pest 1866; Kurzgefasster Schematismus der evangelischen Kirche augsburgischen und helvetischen Bekenntnisses in Böhmen u. Mähren, Ober-Kraupen 1877; Az erdelyi reformata anyaszentegyhaz Nevkönyve. (Schematismus der reformirten-Kirche von Siebenbürgen), Klausenburg 1859-; Schematismus der Evangelischen Kirche Augsburgischen und Helvetischen Bekenntnisses in Österreich 1913, Wien 1913. 
także roczniki personalne dla niektórych miast monarchii ${ }^{13}$. W końcu wymienić należy szematyzmy „prywatne”, obejmujące np. spisy osób zatrudnionych w dobrach poszczególnych rodzin arystokratycznych ${ }^{14}$.

Częściowo manierę urzędowego publikowania spisów osób pełniących funkcje administracyjne czy wojskowe przejęła II Rzeczypospolita ${ }^{15}$. Po 1945 r. zaniechano w Polsce wydawania roczników sprawozdawczych urzędników.

W literaturze polskiej szematyzmy z czasów austriackich funkcjonują jedynie na przykładzie periodyków poświęconych Galicji. Wymienić tutaj należy artykuły Henryki Kramarz wraz z przyczynkami polemicznymi Mariana Tyrowicza, zamieszczone w krakowskich "Studiach Historycznych"16. Ponadto pamiętać należy o artykule Ewy Szczygieł, zamieszczonym we wspomnianych „Studiach”, w którym autorka wykorzystuje szematyzmy galicyjskie do stworzenia przekroju narodowościowego starostów terenów zachodniej części Galicji (Bochnia, Tarnów, Rzeszów, Jasło, Nowy Sącz, Wadowice) w pierwszej połowie XIX w. (lata 1799$1854)^{17}$. Szematyzmami wojskowymi, na przykładzie wydania z 1918 r., zajął się Stefan Jellenta. Jego artykuł to próba wychwycenia oficerów-Polaków służących w c.k. armii podczas I wojny światowej i przedstawienie ich dalszych losów ${ }^{18}$. Wymienione artykuły nie wyczerpują jednak tematu szematyzmów austriackich jako źródeł do historii ziem polskich. Niniejszy tekst również nie pretenduje do bycia pełną wykładnią tematu. Może stanowić jedynie kolejny przyczynek, pokazujący temat $z$ odmiennej perspektywy i w innym zasobie.

Szematyzmy wojskowe w monarchii austriackiej (austro-węgierskiej) ukazywały się pod różnymi tytułami. Początkowo, od 1790 r., był to Oesterreichischer Militär-Almanach für das Jahr..., numerowany również jako Militär-Almanach

13 Schematismus der Stadt Innsbruck für das Jahr 1837, Innsbruck 1837; Orientirungs-Schematismus der königlichen Kreisstadt Pilsen, Pilsen 1879; Schematism mesta Zizkova, Prag 1886; Schematismus für die königl. Hauptstadt Brünn sammt allen Vorstädten, Brünn 1853-; Hof- und Staats-Schematismus der röm. kais. auch kais. königlich- und erzherzoglichen Haupt- und Residenzstadt Wien, Wien 1776-1804; Maly schematismus, cili seznam ulic a namesti kral. hlavniho mesta Prahy.(Kleines Häuserschema oder Gassen- und Plätze-Verzeichniss der kgl. Hauptstadt Prag), Prag 1870; Szematyzm członków gminy miasta Tarnowa poświęca Jan Krzywonos woźny magistratu na Nowy Rok 1861 (rok pierwszy wydania), Tarnów 1860; Schematismus von Olmütz, Olmütz (Ołomuniec) 1872.

14 Schematismus des gesammten hochfürstlich Johann Liechtensteinschen Forstbesitzes, OImütz (Ołomuniec) 1873-; Knizeci Schwarzenbergsky Sematismus. (Fürstlich Schwarzenbergischer Schematismus des ersten und zweiten Majorates. Redigirt von M. Bloch.), Budweis 1893-.

${ }^{15} \mathrm{~W}$ dwudziestoleciu międzywojennym ukazywały się spisy oficerów Wojska Polskiego, np. Rocznik Oficerski 1923, Warszawa 1923.

${ }^{16}$ H. K r a m a r z, Schematyzmy galicyjskie jako źródło historyczne, „Studia Historyczne” 1982, t. .XXV, z. 1, s. 27-48; M. Ty r o w i c z, Kilka uwag o schematyzmach galicyjskich jako źródle historycznym, „Studia Historyczne” 1983, t. XXVI, z.4, s. 699-701; H. K r a m a r z, Jeszcze w sprawie schematyzmów galicyjskich, „Studia Historyczne” 1985, t. XXVIII, z. 4, s. 633-635; t a ż, Schematyzmy galicyjskie (1776-1914) jako c.k. rocznik sprawozdawczy dotyczący obsady kadrowej władz, urzędów, towarzystw i instytucji, „Rocznik historii prasy polskiej” 2007, t. X, z. 1, s. 5-29.

17 E. S z c z y g i e ł, Starostowie cyrkularni Zachodniej Galicji w latach 1799-1854 w świetle tzw. szematyzmów galicyjskich, „Studia Historyczne” 2005, t. .XLVIII, z. 2, s. 191-205.

${ }^{18} \mathrm{~S}$. J e II e n ta, Ostatni austriacko-węgierski rocznik oficerski, „Studia Historyczne” 1978, t. XXI, z.1, s. 107-137. 
Nro... W latach 1804-1808 rocznik ukazywał się pod tytułem: Schematismus der Kais. Königl. Armée für das Jahr... (Militär-Almanach Nro XV-XIX). W latach 1810-1814, w związku ze zmianą tytulatury cesarskiej, rocznik wojskowy nosił tytuł Schematismus der Oesterreichisch-Kaiserlichen Armee für das Jahr... (numery XX-XXIV). Po 1815 r. szematyzmy wojskowe nosiły tytuł Militär-Schematismus des österreichischen Kaiserthums für das Jahr... Po 1870 r. i zmianach statusu państwa na dualistyczną monarchię oraz związanym z tym podziałem armii doszło także do podziału wojskowych roczników sprawozdawczych. Każdy z głównych członów armii, czyli armia wspólna (Heer), austriacka obrona krajowa (Landwehr) oraz węgierska obrona krajowa (Honved) otrzymały własne roczniki sprawozdawcze. Należy pamiętać o tym, że rocznik armii wspólnej obejmował także obsadę personalną i struktury marynarki wojennej, zaś roczniki poszczególnych obron krajowych także opisywały formacje żandarmerii19. Do roku 1889 szematyzmy dla armii wspólnej nosiły nazwę: Kais. Königl. Militär-Schematismus für..., zaś od 1890 r. - Schematismus für das kaiserliche und königliche Heer und für die kaiserliche und königliche Kriegsmarine für... W czasach I wojny światowej (od 1916 r.) roczniki wojskowe funkcjonowały jako Ranglisten des kaiserlichen und koniglichen Heeres.

Objętość periodyku wykazywała wyraźną tendencję wzrostową, np. w 1792 r. szematyzm (almanach wojskowy) liczył 254 strony, w 1801 r. objętość wynosiła 300 stron, w 1815 r. było to ponad 530 stron, a w 1850 r. ponad 800 stron. W 1868 r. objętość rocznika wyniosła 1100 stron, zaś po zmianach w strukturze armii rocznik dla wojska wspólnego na 1871 r. liczył prawie 1170 stron. W 1900 r. na rocznik składało się już 1500 stron. Lista rang dla 1918 r. wypełniała prawie 2300 stron.

Austriackie wojskowe periodyki sprawozdawcze były teoretycznie rocznikami. Wyjątkiem od tej zasady stały się dwa wydania Militär-Schematismus des österreichischen Kaiserthums für das Jahre: za lata 1860/1861 i 1861/1862. Warto także pamiętać o pojedynczych latach, w których z różnych powodów nie wydano szematyzmu (z powodu wojny oraz problemów wewnętrznych państwa austriackiego nie ukazał się rocznik 1849). Podobnie nie ukazał się rocznik na 1869 r. Nie dotarłem także do rocznika 1809. Jednak przy ciągłej numeracji pozostałych wydań wszystko wskazuje, że ten rocznik w ogóle się nie ukazał.

Szematyzmy wojskowe, w przeciwieństwie do szematyzmów lokalnych, publikowane były przez cały okres w języku niemieckim. Część, w różnych okresach, prowadzona była w językach krajowych ${ }^{20}$. Używano czcionki łacińskiej lub gotyckiej.

${ }^{19}$ Dla austriackiej obrony krajowej rocznik od 1871 r. nosił tytuł: Schematismus der Landwehr der im Reichsrathe vertretenen Königreiche und Länder, zaś od 1904 Schematismus der k.k. Landwehr und der Gendarmerie der im Reichsrate vertretenen Königreiche und Länder; dla węgierskiej - A magyar kiralyi honvedelmi ministerium, a honvedseg es csendörseg Nevkönyve rendfokozati es beosztasi kimutatassal.

20 Szematyzmy galicyjskie ukazywały się w latach 1781-1782 oraz po 1869 r. w języku polskim, zaś pierwsze zachowane wydanie z 1776 r. było w języku francuskim pt. Almanach Royal de Gallicie et de Lodomerie pour L'année 1776. Il se trouve au Bureau de la Direction générale des Gazettes, des annonces publiques, des chaises a porteurs etc. sur la place de la maison de Ville, vis à vis Hôtel des douannes Impériales. A Leopol, chez Antoine Piller, Imprimeur du Gouvernement. 
Pierwsze dwadzieścia pięć roczników wojskowych ma dość prostą strukturę, sprowadzającą się do rozpoczynającego wydanie kalendarza na nadchodzący rok, a następnie strona po stronie spisu generałów, oficerów i urzędników wojskowych, uszeregowanego według rodzajów broni, jednostek i instytucji wojskowych. W obrębie jednostek osoby uporządkowane zostały według stopnia wojskowego oraz starszeństwa ${ }^{21}$. Dopiero od 1815 r. można mówić o realnej użyteczności roczników wojskowych jako źródła historycznego. Roczniki z lat 1815-1817 noszą wyraźne znamiona form przejściowych. Jest jeszcze kalendarz na bieżący rok, ale szczegółowość danych jest o wiele lepsza ${ }^{22}$. Zaczyna się również rysować struktura wewnętrzna wydawnictwa, konsekwentna dla kolejnych roczników praktycznie aż do końca istnienia naddunajskiej monarchii. Roczniki miały zazwyczaj następujące stałe elementy: spis treści i lista skrótów, genealogia domu cesarskiego, centralne władze wojskowe, wojskowe władze terytorialne, lista feldmarszałków, generałów i pułkowników ${ }^{23}$, adiutantura, dowództwa twierdz, miast i placów ${ }^{24}$, kawalerowie Orderu Marii Teresy ${ }^{25}$, gwardie, formacje wojskowe (piechota, kawaleria, artyleria, wojska inżynieryjne i techniczne, Marynarka Wojenna, zakłady wojskowe, służby ${ }^{26}$, zmiany zaszłe $w$ trakcie druku (Veränderungen während des Druckes), indeksy.

Zmiany struktury wewnętrznej wydawnictwa w XIX w. były niewielkie i dość powolne. Główną tendencję stanowiła rosnąca objętość i szczegółowość periodyku oraz coraz lepsze indeksowanie. Genealogia domu cesarskiego pojawiła się po raz pierwszy w 1817 r. Pełne indeksy osobowe zamieszczono w 1825 r., do tego czasu w wydawnictwach funkcjonował jedynie, mniej lub bardziej dokładny, indeks „pułkowy”, obejmujący „właścicieli”27 (obecnych i minionych) poszczególnych formacji wojskowych. Ponadto, przynajmniej od 1805 r., do wydawnictwa dodawano indeks rzeczowy. W roczniku na 1835 r. po raz pierwszy zamieszczono spis treści. W strukturze wydawnictwa pojawiały się także sukcesywnie listy starszeństwa

${ }^{21}$ W pierwszych almanachach ograniczono się tylko do oficerów sztabowych, tj. od stopnia majora włącznie wzwyż. Wyjątkiem od tej reguły były gwardie, jednakże stopnie oficerskie były tam tylko honorowe i zazwyczaj obsadzane przez generałów.

${ }^{22}$ Przy poszczególnych jednostkach i instytucjach pojawiają się osoby noszące stopień chorążego (Fahnriche) oraz mu odpowiadające.

${ }^{23}$ Osobno prowadzone dla osób z przydziałami i bez przydziałów (Angestellte oraz Unangestellte).

${ }^{24}$ Festung-, Stadt- und Platz-Commando.

25 Uporządkowani wg daty uzyskania odznaczenia.

${ }^{26} \mathrm{~W}$ tym szkoły wojskowe.

${ }^{27} \mathrm{~W}$ armii austriackiej (austro-węgierskiej), podobnie zresztą jak w niemieckiej, panował zwyczaj określania jednostek nie kolejnymi numerami czy nazwami miejscowości, ale za pomocą nazwisk ich dowódców/założycieli. Numery większość jednostek otrzymała dopiero w 1769 r. Wcześniej jednostki były nazywane od nazwiska tzW. „właściciela” (Inhaber), później zaś nazwiska właściciela używano łącznie z numerem. „Właściciel” pułku był to honorowy dowódca oddziału (czasem rzeczywisty), zazwyczaj wojskowy wysokiej rangi lub członek europejskiej dynastii panującej. Charakterystyczna była dość duża rotacja przy nazewnictwie jednostek. W momencie, gdy dany „właściciel” umierał, jego rolę przejmowała inna osoba, a co za tym idzie zmieniała się nazwa jednostki. Wyjątkiem była część formacji, która swojego patrona otrzymywała "na wieczne czasy”. Np. prawie w całości polski 2. pułk ułanów nosił, praktycznie od swojego powstania nazwę ułanów Schwarzenberga (Die Schwarzenberger-Uhlanen) od nazwiska feldmarszałka Karola Filipa Schwarzenberga. W takich przypadkach zazwyczaj dodawano tzw. „drugiego właściciela” spośród żyjących wojskowych. 
(Rangliste) oficerów poszczególnych broni i służb. Początkowo były to jedynie uporządkowane spisy dla formacji technicznych, następnie (od 1865 r.) dla oficerów strzelców, od rocznika dla 1868 r. - dla wszystkich rodzajów broni i służb. Do 1858 r. część członów wydawnictwa (genealogia cesarska, indeksy osobowe) była numerowana oddzielnie lub wręcz nienumerowana (uzupełnienia, listy skrótów).

\section{Sprawy oświatowe}

Chcąc opisać zagadnienia oświatowe, przeprowadziłem przegląd kilku roczników: 1819, 1835, 1850, 1865, 1896.

Szematyzm dla roku 1819 zawiera niewiele informacji na temat oświaty. W tym roczniku rozrzucone są informacje o obsadzie personalnej i strukturze siedmiu instytucji oświatowych. Wymienia się mianowicie, w kolejności pojawienia się w tekście: Wojskowy Instytut Ekwitacyjny (Jeździecki) w Wienner Neustadt (Militär-Equitations-Institut), Akademię Inżynieryjną w Wiedniu (Ingenieurs-Akademie), Akademię Wojskową w Wienner Neustadt (Militär-Akademie), Wojskowy Dom Wychowawczy w Mediolanie (Militär-Erziehungs-Haus), Kompanię Kadetów w Ołomuńcu (Cadetten-Compagnie zu Ollmütz), Kompanię Kadetów w Grazu (Cadetten-Compagnie zu Grätz), Medyko-Chirurgiczną Akademię Józefińską w Wiedniu (Medizinisch-chirurgische Josephs-Akademie) oraz Instytut Kształcenia Córek Oficerów w Herrnals koło Wiednia (Officiers-Töchter-Bildungs-Institut).

Wojskowy Instytut Ekwitacyjny w 1819 r. obsadzało czterech oficerów - komendant i nauczyciele jazdy. Ich zwierzchnikiem był inspektor szkoły, wówczas feldmarszałek porucznik ${ }^{28}$ Józef Radetzki29.

Akademia Inżynieryjna podlegała arcyksięciu Janowi Chrzcicielowi jako dyrektorowi generalnemu. Podlegali mu dyrektor i dwóch inspektorów szkoły ${ }^{30} .9$ oficerów pełniło funkcje nauczycieli przedmiotów wojskowych, 5 młodszych oficerów - funkcje oficerów inspekcyjnych ${ }^{31}$.

Akademia Wojskowa w Wienner Neustadt w 1819 r., podobnie jak Akademia Inżynieryjna, podlegała arcyksięciu Janowi Chrzcicielowi - dyrektorowi generalnemu. Miał on do pomocy cywilnego referenta. Niżej w hierarchii stali: dyrektor lokalny (Local-Direction), sztabu i wyższej inspekcji (4 wyższych oficerów i profos) oraz dwóch dywizjonów (I-II) podzielonych na dwie kompanie (I-IV) każdy. Oba dywizjony miały na stanie w sumie 12 oficerów-inspektorów kompanii, 16 sierżantów-inspektorów klas, 4 wartowników (Führer zur Wache) oraz 4 doboszy (Tambour). Grono nauczycielskie składało się z trzech grup: oficerów, duchownych oraz pracowników cywilnych. 8 oficerów wykładało przedmioty przydatne przyszłym

${ }^{28}$ Feldmarschall-Lieutenant - odpowiednik polskiego stopnia generała dywizji.

${ }^{29}$ Militär-Schematismus des österreichischen Kaiserthums für das 1819 Jahr, Wien 1819, s. 398.

30 Jeden jako inspektor studiów, drugi jako inspektor dyscypliny i spraw ekonomicznych.

${ }^{31}$ Przy czym najstarszy rangą z nich pełnił równolegle funkcję dowódcy przydzielonej do służby przy akademii kompanli saperskiej. Militär-Schematismus... 1819, s. 404-405. 
oficerom (sztuka wojenna, matematyka, geometria itp.). 9 duchownych zajmowało się nauką religii, filozofii, retoryki oraz języków. 5 pracowników cywilnych uczyło np. tańca czy pływania. W strukturze akademii wojskowej występowała też, jako oddzielna komórka, szkoła jazdy. Jeździectwa uczyło 2 oficerów mających do pomocy personel składający się z wachmistrza-mistrza woltyżerki, kowala, siodlarza, kaprala i 12 dragonów. Opieką nad zdrowiem elewów zajmowało się 3 lekarzy oraz 6 sanitariuszy. Pracami administracyjnymi i ekonomicznymi zajmowało się 2 urzędników, wspomaganych przez 6 żołnierzy. Personel pomocniczy akademii składał się z przynajmniej 80 ludzi (spis funkcji kończy się zwrotem: „etc."). W sumie w ramach obsady akademii wymienić można 42 osoby personelu nauczającego, 3 urzędników, 3 lekarzy oraz 134 osoby personelu pomocniczego ${ }^{32}$.

Mediolański Wojskowy Dom Wychowawczy zajmował się opieką nad dziećmi oficerów i żołnierzy służących na terenie północnych Włoch. Jego strukturę tworzyli: podpułkownik jako komendant domu, pięciu oficerów (kapitanów i poruczników) nauczycieli, kapelan (pełniący równocześnie funkcje nauczyciela religii i języka włoskiego) oraz lekarz ${ }^{33}$.

Kompanię Kadetów w Ołomuńcu nadzorował komendant miejscowej twierdzy jako inspektor. Przedmioty wojskowe i techniczne wykładał zarówno komendant kompani, jak i 7 innych oficerów (1 etat nieobsadzony). W strukturze kompanii znalazło się także miejsce dla kapelana oraz lekarza. Funkcje pomocnicze obsadzało 42 podoficerów i żołnierzy ${ }^{34}$.

Kompania Kadetów w Grazu miała zdecydowanie mniejszą obsadę niż ołomuniecka. Szematyzm z 1819 r. wymienia w jej składzie jedynie pięciu oficerów, przy czym komendant nie pełnił jednocześnie funkcji nauczycielskich, tak jak w Ołomuńcu ${ }^{35}$.

Następną w kolejności wystąpienia, choć wyższą, jeżeli chodzi o status, była Medyko-Chirurgiczna Akademia Józefińska w Wiedniu. Szematyzm z 1819 r. wymienia 10 lekarzy będących jej członkami oraz funkcje wojskowe, jakie pełnili oprócz tego zaś - obsadę biblioteki i prosektorium ${ }^{36}$.

Ostatnią instytucją oświatową figurującą w szematyzmie za 1819 r. był Instytut dla Córek Oficerów w Herrnal koło Wiednia. Dość krótki opis instytutu wymienia 3 nauczycielki, kapelana oraz lekarza ${ }^{37}$.

Rocznik wojskowy na 1835 r. przynosi zdecydowanie więcej informacji o oświacie niż opisany wcześniej. Szkoły wojskowe zostały uporządkowane wg klucza hierarchicznego - od najwyższych do najniższych. Ponadto pojawiła się część poświęcona szkołom na terenie pogranicza wojskowego. Akademia Medyko-Chirurgiczna nadal pozostała oddzielona od części poświęconej oświacie wojskowej. Na zakończenie tomu zamieszczono spis fundacji osób prywatnych na cele wojskowe. W treści rocznika nie pojawia się już instytut ekwitacyjny.

\footnotetext{
32 Tamże, s. 405-407.

33 Tamże, s. 407-408.

34 Tamże, s. 408.

35 Tamże, s. 409.

36 Tamże, s. 414-415.

37 Tamże, s. $414,440$.
} 
Akapit poświęcony Akademii Inżynieryjnej zaczyna się od listy stypendiów państwowych, krajowych i prywatnych dla elewów. 3 stypendia państwowe obejmowały 32 miejsca (w tym 20 dla mieszkańców Galicji), zaś 9 prywatnych -28 miejsc. Struktura organizacyjna w 1835 r. składała się z dyrektora generalnego, 3 oficerów w dyrekcji lokalnej, 20 oficerów, adiutanta, profosa oraz kompanii saperskiej3.

Akademia Wojskowa w Wienner Neustadt w 1835 r. miała w strukturze dyrektora generalnego, 6 oficerów w dyrekcji lokalnej, 16 oficerów - inspektorów dywizjonów i kompanii, 21 nauczycieli, 2 oficerów w szkole jazdy, 4 urzędników, 3 lekarzy oraz 129 osób personelu pomocniczego. Szematyzm ten wymieniał także stypendia: 4 państwowe dla 328 oraz 10 krajowych dla 115 elewów (w tym dla 20 z Galicji $)^{39}$.

Nowym elementem struktury pojawiającym się w szematyzmie na $1835 \mathrm{r}$. było Kolegium Kadetów Marynarki w Wenecji (Marine-Cadeten-Collegium zu Venedig). Na czele stał kapitan korwety ${ }^{40}$ z zastępcą administracyjnym. Grono nauczycielskie liczyło 2 profesorów cywilnych (prawnik i szkutnik) oraz 4 wojskowych (porucznik i 3 chorążych). Dodatkowo 4 oficerów pełniło równoczesne funkcje inspekcyjne i wykładowcze. Religię prowadził kapelan marynarki. Kolegium obsługiwało 20 osób personelu ${ }^{41}$.

Kompania Kadetów w Ołomuńcu w 1835 r. liczyła (obok komendanta) 8 oficerów jako nauczycieli i inspektorów, kapelana będącego nauczycielem religii oraz 45 osób personelu pomocniczego ${ }^{42}$. Kompania Kadetów w Grazu w 1835, w przeciwieństwie do 1819 r., miała już strukturę zbliżoną do tej z Ołomuńca. Inspektorem szkoły był dyrektor dystryktu fortyfikacyjnego dla llirii i Dolnej Austrii. Obsada szkoły składała się z komendanta, 8 oficerów - nauczycieli i inspektorów, kapelana oraz 47 osób personelu ${ }^{43}$.

W porównaniu z 1819, do roku 1835 została znacznie rozbudowana sieć wojskowych domów wychowawczych. Obok wymienionego w 1819 r. domu w Mediolanie $^{44}$, w 1835 r. wzmiankowane są osobne placówki, uporządkowane według poszczególnych pułków piechoty: dla 8 pułków lombardzko-weneckich, 13 pułków galicyjskich, 40 pozostałych pułków liniowych oraz 2 pułków pogranicza wojskowego. W roczniku wojskowym na 1835 r. znajdujemy konkretne informacje na temat rozmieszczenia i struktury poszczególnych typów zakładów wychowawczych dla chłopców. Instytut wychowawczy w Mediolanie wg tych informacji miał miejsca dla 250 synów żołnierzy. Szematyzm wymienia generała majora jako komendanta instytutu, 6 oficerów inspekcyjnych i nauczających, kapelana, lekarza oraz przy-

38 Tamże, s. 422-423.

39 Tamże, s. 424-427.

40 Odpowiednik stopnia majora w wojskach lądowych.

41 Militär-Schematismus des österreichischen Kaiserthums für das 1835 Jahr, Wien 1835, s. $427-428$.

42 Tamże, s. 428.

43 Tamże, s. 429.

44 Który w 1835 r. wzmiankowany był pod nazwą Wojskowy Instytut Wychowawczy dla Chłopców (Militär-Knaben-Erziehungs-Institut zu Mailand). 
najmniej 44 pomocników niższych rang. W przypadku galicyjskich domów wychowawczych dla chłopców informacje o strukturze są dość lakoniczne i ograniczają się jedynie do lokalizacji oraz osoby komendanta ${ }^{45}$. Limity miejsc w każdym z nich wynosiły 48. Informacja o domach wychowawczych pozostałych pułków liniowych ograniczają się do wzmianki o limicie miejsc dla 48 uczniów ${ }^{46}$ i lokalizacji w miejscu stacjonowania jednostek. Dla pułków pogranicznych istniały dwa domy dla 150 chłopców $^{47}$.

W szematyzmie na 1835 r. pojawia się (jako nowość w stosunku do 1819 r.) część poświęcona cywilnym szkołom na terenie pogranicza. Została wymieniona obsada personalna jedynego gimnazjum na tym terenie oraz 26 niemieckich szkół wyższych. W przypadku gimnazjum mamy do czynienia z podaniem pełnej obsady. W przypadku szkół niższego poziomu redaktorzy ograniczyli się jedynie do wskazania kierowników poszczególnych szkół i podania sumarycznej liczby nauczycieli na terenie konkretnych generalitatów ${ }^{48}$.

W przypadku Akademii Medyko-Chirurgicznej w 1835 r. doszło do dość znacznego poszerzenia informacji na temat struktury, co być może jest związane z rozbudową instytucji. Wymieniono dyrektora, wicedyrektora, 13 profesorów, 3 lekarzy, 6 asystentów, bibliotekarza, notariusza, prosektora i 6 osób personelu pomocniczego ${ }^{49}$.

Ostatnią, także rozbudowaną w stosunku do 1819 r., instytucją oświatową obecną w szematyzmie z 1835 r. jest Instytut dla Córek Oficerów w Herrnals, liczący 40 miejsc. Wśród personelu figurują 3 nauczycielki, katecheta, 3 lekarzy, kapelmistrz (Musikmeister), nauczycielka kaligrafii (Zeichenmeisterin) oraz mistrz tańca (Tanzmeister) ${ }^{50}$.

W strukturze rocznika pojawiło się kolejne novum w stosunku do 1819 r., mianowicie fundacje (Stiftungen). Poza osobno wypunktowanymi przy akademiach wojskowych stypendiami wymieniono 103 inne fundacje. 21 z nich wspierało oświatę wśród młodzieży wojskowej, 8 wiązało się z działalnością wojskowych domów wychowawczych, pozostałe obejmowały dążenia do zdobycia wykształcenia wśród młodzieży np. fundowanie zakupu wyposażenia dla kadetów czy kandydatów lekarskich ${ }^{51}$.

Szematyzm za rok 1850, wydany tuż po wydarzeniach związanych z Wiosną Ludów, przynosi kolejne informacje o oświacie wojskowej. Od poprzednio opisywanego rocznika różni się tym, że nie zawiera informacji o Akademii Medyko-Chirurgicznej. W zamian dostajemy o wiele dokładniejszy i klarowny opis struktur oświatowych na terenie pogranicza wojskowego. Odnośnie do poszczególnych instytucji otrzymujemy nowe informacje o ich strukturze.

45 Galizische-Soldaten-Knaben-Erziehungshaus w 1835 r. funkcjonowały we Lwowie, Starym Mieście, Przemyślu, Cieszynie, Znaim, Bartfeld i w Sternberg na Morawach.

${ }^{46}$ Z wyjątkiem pułków morawskich, w których domach wychowawczych zarezerwowano po 28 miejsc dla synów żołnierzy obrony krajowej.

47 Militär-Schematismus... 1835, s. 430-431.

48 Tamże, s. 431-433.

49 Tamże, s. 443-446.

50 Tamże, s. 467.

51 Tamże, s. 469-487. 
Akademia Inżynieryjna uzyskała dodatkowe miejsca stypendialne, zamiast 32 z funduszy państwowych w 1835-44 w 1850 r. Podobny wzrost dotyczył miejsc fundowanych przez osoby prywatne. 12 fundatorów zapewniało finansowanie 37 elewów (o 9 więcej niż w 1835 r.). Struktura akademii przedstawiała się podobnie jak w 1835 r. Nadrzędną władzę sprawował dyrektor generalny w randze feldmarszałka-porucznika. Podlegał mu dyrektor lokalny w takiej samej randze, mający do pomocy adiutanta. Grono nauczycielskie składało się z 14 oficerów, 8 cywilów oraz 2 duchownych. Rolę nauczycieli-inspektorów odgrywało 21 oficerów. W strukturze szkoły działała także kompania saperska dowodzona przez kapitana, mającego do pomocy 14 podoficerów inspekcyjnych. Za zdrowie nauczycieli i elewów odpowiadało 4 lekarzy i 6 sanitariuszy. Obsługą administracyjną instytucji zajmowało się 4 urzędników. Personel pomocniczy składał się z 63 osób.

Akademia Wojskowa w Wienner Neustadt także zachowała strukturę zbliżoną do tej z 1835 r. W 1850 r. państwo fundowało 361 miejsc, zaś poszczególne kraje koronne - dalsze 83 miejsca. Szematyzm przynosi także informacje o strukturze poszczególnych kompanii szkolnych: IV składała się z elewów klasy przygotowawczej i pierwszej, III z elewów drugiej i trzeciej klasy (obie tworzyły drugi dywizjon), II składała się z uczniów klasy czwartej i piątej, a I - z najstarszych uczniów klas szóstej i siódmej. Jednakże w 1850 r. klasa siódma nie istniała ${ }^{52}$. Pierwsza i druga kompania formowały razem pierwszy dywizjon. Na czele uczelni stał dyrektor lokalny, mający do pomocy 5 oficerów w sztabie. Przy poszczególnych kompaniach szkolnych pozostawało 19 oficerów-nauczycieli, 6 kolejnych oficerów, 5 duchownych oraz 7 cywilów pracujących jako nauczyciele. Duchowny, emerytowany nauczyciel, był bibliotekarzem. W akademickiej szkole jeździeckiej pracowało 2 oficerów. Opieką medyczną zajmowało się 4 lekarzy, obsługą administracyjną 3 urzędników. Personel pomocniczy składał się ze 128 osób ${ }^{53}$.

Nową jednostką oświatową, niewymienioną w 1835 r., był Centralny Wojskowy Instytut Ekwitacyjny w Salzburgu (Militär-Central-Equitations-Institut). Informacje o strukturze szkoły ograniczają się tylko do podania nazwisk inspektora i wicekomendanta. Adnotacja o wakacie na stanowisku komendanta i brak jakichkolwiek dokładniejszych danych wskazywałyby, że jest to nowo powstała instytucja ${ }^{54}$.

Informacje o Kolegium Marynarki w Trieście ograniczają się do wymienienia dwóch oficerów w dyrekcji, 6 profesorów (4 oficerów, kapelan i cywil) i oficera inspekcyjnego, opiekujących się 20 wychowankami55.

Kompanie Kadetów w Ołomuńcu i Grazu, podobnie jak w 1835 r., miały zbliżoną strukturę. W Ołomuńcu byli inspektor, komendant, 9 oficerów-nauczycieli, kapelan, 46 osób personelu pomocniczego oraz 168 uczniów, a w Grazu - inspektor, komendant, 8 oficerów-nauczycieli, kapelan, 50 osób personelu pomocniczego, 180 uczniów ${ }^{56}$.

52 Być może wiązało się to z wojennym trybem awansu najstarszych roczników podczas Wiosny Ludów.

53 Militär-Schematismus...1850, s. 536-539.

54 Tamże, s. 519.

55 Tamże, s. 539-540.

56 Tamże, s. 540-542. 
W domach wychowawczych zaszły pewne zmiany w stosunku do 1835 r. Wojskowy Instytut Wychowawczy dla Chłopców w Mediolanie w 1850 r. nie był wzmiankowany. Jak się wydaje, jego rolę przejęły dwa domy: w Bergamo i Cividale (każdy dla 48 chłopców). Inne domy wychowawcze pozostały bez zmian w porównaniu z 1835 r. W 7 domach galicyjskich znalazło się miejsce dla 336 chłopców, w 40 domach liniowych pułków piechoty dla 1920 chłopców, zaś w 2 domach na pograniczu wojskowym dla 150 chłopców. W sumie dawało to 2406 miejsc $^{57}$.

Na terenie pogranicza wojskowego w 1850 r. wymienione są dwa gimnazja (wyższe w Zengg w generalitacie Carstadt i zwykłe w Vinkowcze w Slawonii) oraz 14 szkół głównych. W gimnazjach pracowało 16 nauczycieli (3 etaty nieobsadzone). Ewenementem były osoby sprawujące funkcje dyrektorów tych dwóch placówek. Normalna była praktyka, że dyrektorem, czyli de facto kontrolerem i cenzorem, był miejscowy starosta, a więc przedstawiciel władzy politycznej. W dwóch wspomnianych placówkach dyrektorami byli odpowiednio miejscowi biskup i generał. W szkołach głównych było 52, w szkołach niższego poziomu 171 nauczycieli ${ }^{58}$.

Ostatnią instytucją oświatową wymienioną w 1850 r. był Instytut dla Córek Oficerów w Herrnal. Personel obejmujący 6 nauczycieli, katechetę i trzech lekarzy opiekował się 40 uczennicami59.

W roczniku 1850 odnotowano 209 fundacji oraz 12 nowych, ustanowionych w latach 1848-1849 (spośród starych 59, zaś spośród nowych 3 wiązały się ze sponsorowaniem oświaty $)^{60}$.

Rocznik 1865 szematyzmu wojskowego widocznie różni się w stosunku do wcześniej analizowanego. Wszystkie zakłady zostały uporządkowane w odwrotnej kolejności niż w poprzednich omawianych latach (od najniższych rangą szkół aż po najwyższe). Ponadto wprowadzono podział wewnętrzny na wojskowe zakłady oświatowe (Militär-Bildungs-Anstaltes) i zakłady wychowawcze dla kobiet (Weibliche Erzichungs-Anstaltes). W ramach wojskowych zakładów oświatowych redaktorzy dokonali dodatkowo podziału na zakłady wychowawcze (Militär-Erziehungs-Anstalten) oraz zakłady szkolne (Militär-Lehr-Anstalten), który pozwalał rozróżniać instytucje zapewniające wykształcenie ogólne od szkół specjalistycznych. Rocznik 1865 był także jednym z ostatnich, w których znalazło się miejsce dla instytucji oświatowych działających na terenie pogranicza wojskowego. Zmienił się także opis fundacji wojskowych. Podzielono je wg grup odbiorców.

Zmieniła się dość znacznie sama struktura oświaty wojskowej. Pojawiły się nowe typy szkół, zastępujące część z dotychczas opisywanych. Nastąpiła także dość znaczna unifikacja struktury wewnątrz poszczególnych grup szkół.

W grupie Militär-Erziehungs-Anstalten redaktorzy wyróżnili domy wychowawcze (Erziehungshäuser), kompanie szkolne (Schul-Compagnien), instytuty kadetów (Cadetes-Institute) oraz akademie wojskowe (Militär-Akademie).

57 Tamże, s. 542-543.

58 Tamże, s. 543-549.

59 Tamże, s. 612.

60 Tamże, s. 614-668. 
W roku 1865 istniały 4 niższe ${ }^{61}$ oraz 5 wyższych ${ }^{62}$ wojskowych domów wychowawczych. Personel każdego z niższych domów składał się z komendanta, kapelana, lekarza (obaj równocześnie pełnili funkcje nauczycieli), 5 sierżantów-nauczycieli oraz 31 osób personelu pomocniczego. W wyższym domu wychowawczym oprócz komendanta pracowało 2 oficerów-nauczycieli. Ponadto, podobnie jak w niższym domu wychowawczym, nauczał kapelan i lekarz oraz 5 sierżantów-nauczycieli. Personel pomocniczy w każdym z tych domów składał się z 48 osób ${ }^{63}$.

Kompanie szkolne dzieliły się wg rodzajów broni. Istniały 2 kompanie piechoty $^{64}, 4$ artylerii ${ }^{65}, 1$ wojsk inżynieryjnych ${ }^{66}, 1$ pionierów ${ }^{67}$. Etat każdej kompanii szkolnej piechoty przewidywał stanowisko komendanta, 2 oficerów, lekarza, 4 sierżantów-nauczycieli oraz 30 osób personelu pomocniczego. W kompaniach artylerii, inżynieryjnej i pionierskiej obok komendanta było 5 oficerów artylerii odpowiednich broni jako nauczycieli, a personel liczył 32 ludzi. W każdej z nich był także lekarz i 4 sierżantów-nauczycieli68.

Cztery instytuty kadetów ${ }^{69}$ miały identyczny etat składający się z komendanta, adiutanta, 14 nauczycieli (12 oficerów i 2 duchownych), 2 lekarzy oraz 60 osób personelu ${ }^{70}$.

W szematyzmie na 1865 r. wymienione są trzy wojskowe wyższe uczelnie: Akademia Wojskowa w Wienner Neustadt (Neustädter-Akademie) dla kawalerii i artylerii, Akademia Artylerii (Artillerie-Akademie) w Weiskirchen na Morawach oraz Akademia Inżynieryjna (Genie-Akademie) w Klosterbruck koło Znaim.

Etat akademii w Wienner Neustadt obejmował komendanta, jego adiutanta, 42 nauczycieli (37 oficerów, 2 kapelanów, 3 cywilów), 2 lekarzy oraz 206 osób personelu. Wśród personelu wymieniono oddział pionierów w składzie: sierżant, 2 kaprali i 50 żołnierzy. W przeciwieństwie do poprzedniego analizowanego rocznika, w opisie akademii nie pojawiły się informacje na temat podziału studentów na lata czy oddziały ${ }^{71}$. Akademia artylerii w Weiskirchen miała na swoim stanie, obok komendanta i adiutanta, 32 nauczycieli (29 oficerów, 2 duchownych, 1 cywil), 2 lekarzy, weterynarza oraz 147 osób personelu (w tym pododdział z 40 kanonierów, sierżanta i 2 kaprali, obsługujących baterię artylerii konnej) $)^{72}$. Akademia Inżynieryjna miała na etacie komendanta, jego adiutanta, 30 nauczycieli (26 oficerów, 2 kapelanów, 2 cywilów), 2 lekarzy oraz 124 osoby personelu pomocniczego, w tym pododdział złożony z sierżanta, 2 kaprali i 40 żołnierzy ${ }^{73}$.

\footnotetext{
61 W Prerau, Fischau (koło Wienner-Neustadt), Bruck au der Leitha, Weiskirchen w Banacie.

62 W Kuttenberg, Strass, Güns, Koszycach oraz Kamenitz koło Peterwardein.

63 Militär-Schematismus des österreichischen Kaiserthums für das 1865 Jahr, Wien 1865, s. 646-649.

64 W Ołomuńcu i Hainburgu.

65 W Pradze, Krakowie, Ołomuńcu i Liebenau koło Grazu.

66 W St. Pölten.

67 W Tulln.

68 Militär-Schematismus... 1865, s. 649-651.

69 W Mainburgu, Eisenstadt, Fiume i Marburgu.

70 Militär-Schematismus... 1865, s. 652-654.

71 Tamże, s. 654-656.

72 Tamże, s. 656-657.

73 Tamże, s. 658-659.
} 
Nowa część rocznika 1865 r. była poświęcona wojskowym zakładom szkolnym (Militär-Lehr-Anstalten). Redaktorzy wymienili w niej 8 instytucji, w których oficerowie i urzędnicy wojskowi mogli poszerzać swoje umiejętności. Były to: Instytut Nauczycieli Wojskowych (Militär-Lehrer-Institut) w Wienner Neustadt, Szkoła Wojenna (Krieg-Schule) w Wiedniu, Wyższy Kurs Artylerii (Höherer Artillerie-Curs), Wyższy Kurs Inżynieryjny (Höherer Genie-Curs), Wojskowa Centralna Szkoła Kawalerii (Militär-Central-Cavallerie-Schule) w Wiedniu, Zakład Kształcenia Administracji Wojskowej (Militär-administrative Lehr-Anstalt) w Wiedniu, Medyko-Chirurgiczna Akademia Józefińska w Wiedniu oraz Instytut Weterynaryjny (Thier-Arzenei-Institut) w Wiedniu. W przypadku większości wymienionych instytucji redaktorzy obok wykazu nauczycieli umieścili także spisy aktualnych studentów.

Instytut Nauczycieli Wojskowych miał w swojej obsadzie (obok komendanta) 12 nauczycieli (5 oficerów, lekarz, cywil, 4 sierżantów) oraz 13 osób personelu pomocniczego ${ }^{74}$.

Szkoła Wojenna w Wiedniu zatrudniała komendanta, jego adiutanta, 12 nauczycieli (10 oficerów, 2 cywilów) oraz 29 osób personelu pomocniczego. W 1865 r. w tej szkole kształciło się 50 oficerów ${ }^{75}$.

Wyższe kursy artylerii i wojsk inżynieryjnych organizowane były przez nauczycieli akademii w Weiskirchen i Klosterbruck. W 1865 r. arkana artylerii i inżynierii wojskowej poznawało na tych kursach odpowiednio 21 i 17 wojskowych ${ }^{76}$.

Centralna Szkoła Kawalerii w Wiedniu była samodzielną strukturą. Miała na etacie komendanta, adiutanta, 5 oficerów-nauczycieli, weterynarza oraz 71 osób personelu pomocniczego. W 1865 r. jazdę konną doskonaliło 42 oficerów ${ }^{77}$.

Zakład Kształcenia Administracji Wojskowej w Wiedniu podlegał organizacyjnie Szkole Wojennej. Miał na etacie 5 nauczycieli (2 wojskowych ze służb prawno-administracyjnych, 3 cywilów z administracji państwowej) oraz 13 osób personelu. W 1865 r. kształciło się w zakładzie 22 uczniów przeznaczonych następnie do pracy na pograniczu wojskowym ${ }^{78}$.

Akademia Medyko-Chirurgiczna pojawiła się w szematyzmie na 1865 r. po przerwie w 1850 r. W roczniku z 1865 r. znajdujemy informacje na temat struktury administracyjnej placówki, liczby studentów oraz ich organizacji w roczniki. $\mathrm{Na}$ czele akademii stał oficer w stopniu pułkownika, mający do pomocy oficera pełniącego funkcje adiutanta i równocześnie oficera ekonomicznego. Kwestiami naukowymi zajmował się dyrektor studiów - doktor medycyny, mający do pomocy sekretarza. Medycynę wykładało 24 lekarzy oraz 5 młodszych lekarzy i urzędników. Personel pomocniczy liczył 67 osób. W 1865 r. w akademii (trzy lata niższego kursu oraz na 6 lat wyższego) kształciło się 371 przyszłych lekarzy ${ }^{79}$.

Struktura Akademii Weterynaryjnej w Wiedniu wyglądała podobnie jak Akademii Medyko-Chirurgicznej. Komendantem był oficer w randze majora, mający

\footnotetext{
74 Tamże, s. 659.

75 Tamże, s. 660-661.

76 Tamże, s. 662.

77 Tamże, s. 663-664.

78 Tamże, s. 664-665.

79 Tamże, s. 665-668.
} 
do pomocy oficera ekonomicznego. Sprawami naukowymi zajmowali się dyrektor studiów i sekretarz. Nauczało 12 osób, było także 2 urzędników i 76 pracowników. W 1865 r. w ramach szkoły kształciło się 108 kandydatów na kowali wojskowych ${ }^{80}$.

Zakłady wychowawcze dla kobiet (Weibliche Erzichungs-Anstaltes) w 1865 r. przedstawiały się zdecydowanie inaczej niż 15 lat wcześniej. Oprócz istniejącego od dawna zakładu dla córek oficerów w Herrnals, w 1865 r. szematyzm wzmiankował także dwie podobne instytucje dla córek żołnierzy i podoficerów. Wymieniony instytut w 1865 r. zatrudniał 14 nauczycieli, dwóch lekarzy i 23 osoby personelu pomocniczego. Instytuty Wychowawcze dla Córek Żołnierzy (Mannschafts-Töchter-Erziehungs-Institute) znajdowały się w Wiedniu ${ }^{81}$ oraz w węgierskim Szathmár (Némethy). W wiedeńskim zakładzie, pozostającym pod patronatem „Jej cesarsko-królewskiej wysokości Karoliny Augusty”, obsada składała się z 6 nauczycielek, kapelana, lekarza oraz 2 osób z personelu, opiekujących się 56 uczennicami. Zakład w Szathmár pozostawał pod patronatem miejscowego biskupa. Jego kadra składała się z 7 nauczycieli, kapelana oraz 2 lekarzy. Kształciło się w nim 45 uczennic ${ }^{82}$.

Rocznik 1865 zawiera dokładny opis systemu oświaty na terenie pogranicza wojskowego. W spisie wymieniono 744 szkoły powszechne, 87 szkół trywialnych (3-klasowych), 19 szkół głównych (4-klasowych), 5 niższych szkół realnych (3-klasowych), 2 wyższe szkoły realne (6-klasowe) oraz dwa gimnazja. W szkołach głównych wykładało w sumie 116 nauczycieli (1 etat nieobsadzony), w szkołach trywialnych 162 (12 etatów nieobsadzonych), w niższych i wyższych szkołach realnych po 21 nauczycieli (1 etat nieobsadzony), w gimnazjach wykładało 22 nauczycieli. Szematyzm nie podawał nawet sumarycznych danych dotyczących obsady nauczycielskiej w szkołach powszechnych ${ }^{83}$.

W roku 1865 redaktorzy zmienili sposób opisu fundacji wojskowych. Zamiast publikowanego dotąd jednolitego spisu, redakcja wyszczególniła fundacje wg typów, osobno dla żołnierzy aktywnej służby (124 fundacje), inwalidów (250), wdów i sierot (67), innych (71) oraz dla instytucji oświatowych. Ten ostatni zaczyna się od tabelarycznego zestawienia liczby miejsc w poszczególnych typach zakładów szkolnych. Było to odpowiednio: z fundacji wojskowych 960 miejsc w akademiach i instytutach kadetów, 2000 miejsc w kompaniach szkolnych i domach wychowawczych, ze stypendiów państwowych i krajowych odpowiednio 162 i 75 miejsc, z 67 stypendiów prywatnych 155 i 201 miejsc. Dodatkowo spis wymieniał 122 stypendia finansowe, 9 stypendiów w akademii medyko-chirurgicznej. Dla zakładów dla córek oficerskich stypendia gwarantowały 75 miejsc oraz 1 stypendium kwotowe. Dla pozostałych zakładów pięć stypendiów zapewniało 48 miejsc i 2 dotacje. W zakładach dla córek żołnierzy stypendia gwarantowały 91 miejsc ${ }^{84}$.

Rocznik 1896 pokazywał kilka tendencji zmian w systemie oświaty wojskowej. Została ona na poziomie podstawowym ujednolicona oraz częściowo dostosowana do systemu oświaty cywilnej. Szematyzm wykazuje także liczną

\footnotetext{
80 Tamże, s. 668-669.

81 Dokładnie na jego ówczesnym przedmieściu Erdberg.

82 Militär-Schematismus...1865, s. 669-671.

83 Tamże, s. 686-696.

84 Tamże, s. 727-846.
} 
grupę specjalistycznych kursów doskonalących na poziomie ponadakademickim. Nie pojawiają się już szkoły cywilne na pograniczu wojskowym, zlikwidowanym w 1873 r. W strukturze rocznika brak także listy fundacji. Przy każdej ze szkół widniała notka $z$ datą powstania oraz krótką historią jej działania.

Opis systemu szkolnego zaczyna się od wyliczenia szkół kadetów (14 dla piechoty oraz po jednej dla kawalerii, artylerii i pionierów), Instytutu Wychowawczego dla Osieroconych Synów Oficerskich w Fischau (Erziehungs-Institut für verwaiste Offiziersöhne), 4 niższych oraz 1 wyższej szkoły realnej. Wszystkie wymienione instytucje miały zbliżoną strukturę: komendant, adiutant, oficer ekonomiczny, personel nauczający i wychowawczy, aspiranci nauczycielscy oraz nauczyciele eksternistyczni. Różna była liczba nauczycieli w trzech ostatnich grupach: w szkołach kadetów było ich od 12 do 30, w instytucie dla sierot 13, w niższych szkołach realnych od 13 do 20 , a w wyższej szkole realnej aż $37^{85}$. W strukturze akademii wojskowych, oprócz zarządu wymienionego przy szkołach niższego szczebla, pojawił się jeszcze rachmistrz ${ }^{86}$. Personel nauczający dla Akademii Wojskowej w Wienner Neustadt liczył 38 ludzi (33 oficerów, 1 cywil, 1 audytor wojskowy, 2 lekarzy, 1 weterynarz), Wojskowa Akademia Techniczna w Wiedniu miała na etacie 32 nauczycieli (25 oficerów, duchownego, audytora wojskowego, 2 lekarzy, weterynarza i 2 cywilów). Rocznik 1896 wymieniał 10 kursów doskonalących dla podoficerów i oficerów. Ich struktura administracyjna była zbliżona do innych szkół wojskowych, tylko w kilku przypadkach pominięto oficera ekonomicznego. W Szkole Wojennej (Kriegschule) uczyło się 197 oficerów pod opieką 21 nauczycieli (17 oficerów, 4 cywilów). Funkcjonowały 4 Techniczne Wojskowe Kursy Fachowe (Technische Militär-Fachcurse): Specjalny Kurs dla Kapitanów Artylerii Polowej i Fortecznej (kurs 3-miesięczny), Artyleryjska Szkoła Strzelecka (kurs wakacyjny), Wyższy Kurs Artyleryjski (kurs stały, 10 nauczycieli, 38 uczniów), Wyższy Kurs Inżynieryjny (kurs stały, 10 nauczycieli, z czego część także wykładała na kursie artyleryjskim, 41 uczniów ${ }^{87}$ ). Spis wymieniał także 14 studentów-wojskowych na uczelniach cywilnych. 2 Kursy Administracyjno-Wojskowe (Administrative Militär-Fachcurse) szkoliły intendentów wojskowych (Militär-Intendanz-Curs - 8 nauczycieli, 75 uczniów) oraz wojskowych urzędników żywnościowych (Militär-Verpflegsverwalter-Curs - 5 nauczycieli, z czego 2 uczyło równocześnie na kursie intendentów, 10 uczniów). Na Kursie Kierowników Budów Wojskowych (Militär-Bauwerkmeister-Curs) 3 nauczycieli szkoliło 37 podoficerów. Jako kurs fachowy funkcjonowała także dwuosobowa Komisja ds. Oceny Kandydatów na Oficerów Sztabowych (Comission zur Beurtheilung der Stabsoffiziers-Aspiranten). Letnia Armijna Szkoła Strzelecka (Armee-Schießschule) miała w swej strukturze 5 oficerów zarządzających i szkoleniowych. W Wojskowym Instytucie Jeździeckim (Militär-Reitlehrer-Institut) 6 nauczycieli uczyło technik jazdy 54 uczniów. Na Wojskowym Kursie Nauczycieli Fechtunku i Gimnastyki, prowadzonym przez Polaka Aleksandra Beryndę-Czajkowskiego, 9 nauczycieli

${ }^{85}$ Schematismus für das kaiserliche und königliche Heer und für die kaiserliche und königliche Kriegs-Marine für $1896 \mathrm{Jahr}$, Wien 1895, s. 897-908.

${ }^{86}$ W przypadku Akademii w Wienner Neustadt także zarządca lasów.

${ }^{87}$ W tym także słynny podczas pierwszej wojny światowej as lotnictwa Emil Uzelać. 
szkoliło 22 oficerów i 28 podoficerów. Na Kawaleryjskim Kursie Telegraficznym w Tuln (Cavallerie-Telegraphen-Curs) 14 nauczycieli szkoliło 19 oficerów i 90 podoficerów. W Wojskowym Instytucie Weterynaryjnym (Militär-Thierarznei-Institut) było 18 nauczycieli i 206 uczniów $^{88}$. Kolejną grupą szkół wymienionych w roczniku 1896 były zakłady dla dziewcząt: dwa dla córek oficerskich w Hernals (39 nauczycieli) i Ödenburg (13 nauczycieli) oraz dwa zakłady dla córek żołnierzy: w Wiedniu-Erdbergu (6 nauczycieli, 6 personelu) i w Szathmár (Némethy) (6 nauczycieli) ${ }^{89}$. Ostatnią wydzieloną grupą w 1896 r. były szkoły Marynarki Wojennej. Tym razem uporządkowane od najwyższego stopnia. Akademia Morska w Fiume (Rjeka), obok komendanta i adiutanta, miała w składzie 29 nauczycieli (15 wojskowych, 14 cywilów), oficera ekonomicznego, lekarza i rachmistrza. Poza tym wymieniono 3 szkoły w bazie floty w Poli (Pula), Morską Niższą Szkołę Realną (7 nauczycieli), Morską Szkołę Ludową dla Chłopców (7 nauczycieli) i Morską Szkołę Miejską dla Dziewcząt (12 nauczycieli) ${ }^{90}$.

\section{Podsumowanie}

Sprawy oświatowe w szematyzmach wojskowych pojawiają się w kilku aspektach. Po pierwsze, dzięki szematyzmom możemy dokładnie odtworzyć strukturę wojskowej sieci oświatowej i jej zmiany. Po drugie, zyskujemy informacje dotyczące programu poszczególnych typów szkół poprzez analizę przedmiotów w nich wykładanych oraz liczebność personelu zajmującego się tym. Kolejnym aspektem są właśnie ludzie zajmujący się oświatą wojskową, wymieniani w rocznikach. Analiza pozwala odtworzyć etapy ich kariery: to, z jakich jednostek się wywodzili (czy do szkół wojskowych kierowano jako nauczycieli oficerów z okolicznych garnizonów, czy też ściągano specjalistów reprezentujących poszczególne dziedziny, nie bacząc na miejsce stacjonowania ich macierzystych jednostek), w jakim stopniu praca w oświacie wpłynęła na dalszy awans zatrudnionych tam oficerów? Czy była odsunięciem na boczny tor, czy też wręcz przeciwnie - nieodłącznym elementem kariery wybitnego sztabowca czy generała? Możemy w końcu dość ostrożnie ustalić narodowość poszczególnych nauczycieli poprzez analizę ich nazwisk oraz domniemanych krajów pochodzenia i służby. Kolejnym zagadnieniem, jakim można się zająć na podstawie szematyzmów wojskowych, jest sprawa różnego nasycenia strukturami oświatowymi poszczególnych krajów koronnych. Dzięki dość prostym zabiegom możemy prześledzić zmiany, jakie zachodziły w tej strukturze, wynikające np. z coraz mocniejszego włączania poszczególnych prowincji w struktury naddunajskiej monarchii czy też z rosnącego znaczenia militarnego tych prowincji jako obszaru rekrutacyjnego. Do 1873 r. i ostatecznej likwidacji tzw. „pogranicza wojskowego” w rocznikach wojskowych pojawiały się

\footnotetext{
88 Schematismus... 1896, s. 909-925.

89 Tamże, s. 926-929.

90 Tamże, s. 930-931.
} 
informacje także o cywilnych szkołach znajdujących się na terenach wzdłuż południowo-wschodnich i południowych granic państwa austriackiego. Nie podlegały one zarządowi wojskowemu i miały specyficzne struktury łączące prerogatywy wojskowe z cywilnymi, dlatego wzmianki o znacznej część szkół znajdujących się na tym obszarze znalazły się w szematyzmach wojskowych. Wspomnieć należy o nadzwyczaj rozbudowanej sieci stypendiów dla uczniów, kadetów i elewów austriackich szkół wojskowych wszystkich poziomów. W rocznikach wojskowych znajdują się informacje o tego typu fundacjach państwowych, krajowych i prywatnych. Często są to informacje bardzo dokładne, zawierające dane darczyńcy, warunki uzyskania stypendium, a także, w późniejszych wydaniach, o tym, kiedy i jaka instytucja państwowa czy krajowa zatwierdziła fundację. Objętość informacji o oświacie w poszczególnych rocznikach przedstawiam w tab. 1.

Ta b e la 1. Informacje o oświacie w poszczególnych rocznikach

\begin{tabular}{|c|c|c|c|}
\hline Rok & Liczba stron & Liczba stron o oświacie & Procentowy udział stron o oświacie \\
\hline 1819 & 631 & 10 & 1,58 \\
\hline 1835 & 726 & 28 & 3,86 \\
\hline 1850 & 1033 & $16+$ fundacje ok. 30 stron & 4,06 \\
\hline 1865 & 1104 & $37+$ fundacje 23 strony & 5,43 \\
\hline 1879 & 959 & 23 & 2,4 \\
\hline 1896 & 1316 & 35 & 2,66 \\
\hline 1923 & 1852 & 44 & 2,38 \\
\hline
\end{tabular}

Ż r ó dło: Obliczenia własne na podst.: Militär-Schematismus des österreichischen Kaiserthums für das..., roczniki: 1819; 1835; 1850; 1865; Kais. Königl. Militär-Schematismus für 1879 Jahr; Schematismus für das kaiserliche und königliche Heer und für die kaiserliche und königliche Kriegs-Marine für 1896 Jahr, Rocznik Oficerski [Wojska Polskiego] 1923.

Na zakończenie przedstawię jeszcze jeden przykład przydatności szematyzmów wojskowych jako źródła umożliwiającego poznanie dziejów oświaty. W 1855 r. w Tarnowie wzniesiono okazały budynek, służący obecnie jako Pałac Młodzieży. W literaturze historycznej obiekt ten funkcjonował jako austriacki szpital wojskowy ${ }^{91}$. Tymczasem na podstawie szematyzmów wojskowych ustaliłem, że jedynym obiektem wojskowym wówczas budowanym był Dom Wychowawczy dla Chłopców ${ }^{92}$. Fakt ten znalazł także potwierdzenie po porównaniu planów architektonicznych obiektu zdeponowanych w Centralnym Archiwum Wojskowym z obecnym kształtem obiektu ${ }^{93}$.

91 Por. Pałac Młodzieży w Tarnowie, [w:] Tarnów - wielki przewodnik, t. 7: Zawale, Tarnów 2000, s. 62-65; A. G o n t a s z e w s k i, Szpital Wojskowy, [w:] Encyklopedia Tarnowa, Tarnów 2010, s. 437.

${ }_{92}$ "Turnau, Joseph v., beauftragt mit der Bauleitung des Mil. Ober-Erziehungshauses zu Tarnow", za: Militär-Schematismus... 1855, s. 596.

${ }_{93}$ Szpital i koszary w Tarnowie, Centralne Archiwum Wojskowe, sygn. Dok.V.I.371.5.43. 